\title{
Pilot Plant Experiences Using Activated Sludge Treatment Steps for the Biodegradation of Textile Wastewater
}

\author{
Lamia Ayed and Amina Bakhrouf \\ Laboratoire d'Analyse, Traitement et Valorisation des Polluants \\ de l'Environnement et des Produits, Faculté de Pharmacie, Monastir
}

Tunisie

\section{Introduction}

Considering both the volume and the effluent composition, the textile industry wastewater is rated as the most polluting among all industrial sectors. Important pollutants are present in textile effluents; they are mainly recalcitrant organics, colour, toxicants and inhibitory compounds (Khelifi et al., 2008).

Textile industries however, have caused serious environmental problems because of the wastewater produced. Most textile industries produce wastewater with relatively high BOD, COD, suspended solids and color. The wastewater may also contain heavy metals depending on the type of coloring substances used. In general, the objective of textile industry wastewater treatment to reduce the level of organic pollutants, heavy metal, suspended solids and color before discharge into the river. Coloring substances are used for dyeing and printing processes. The wastewater from these two processes is the most polluted liquid waste in a textile industry. Biological, chemical, physical or the combination of the three treatment technologies can be used to treat textile industry liquid waste (Suwardiyno and Wenten, 2005). It has been proven that some of these dyes and/or products are carcinogens and mutagens (Manu and Chaudhari 2003). A part from the aesthetic deterioration of the natural water bodies, dyes also cause harm to the flora and fauna in the natural environment (Kornaros and Lyberatos 2006). So, textile wastewater containing dyes must be treated before their discharge into the environment (Forgas et al., 2004). Numerous processes have been proposed for the treatment of coloured waste water e.g., precipitation, flocculation, coagulation, adsorption and wet oxidation (Hongman et al., 2004; Thomas et al., 2006). All these methods have different colour removal capabilities, capital costs and operating speed. Among these methods coagulation and adsorption are the commonly used; however, they create huge amounts of sludge which become a pollutant on its own creating disposal problems (Nyanhongo et al., 2002). Among low cost, viable alternatives, available for effluent treatment and decolourization, the biological systems are recognised, by their capacity to reduce biochemical oxygen demand (BOD) and chemical oxygen demand (COD) by conventional aerobic biodegradation (Forgas et al., 2004; Kornaros and Lyberatos 2006; Balan and 
Monteiro, 2001). Work on the use of combined bacterial process to treat textile wastewater has been carried out over the years by many research groups. Recent study has used the combination of anaerobic and aerobic steps in an attempt to achieve not only decolourization but also mineralization of dyes (Forgas et al., 2004; Ong et al., 2005). Aerobic processes have been recently used for the treatment of textile wastewater as standalone processes (Khelifi et al., 2008) and it is confirmed that they are efficient, costeffective for smaller molecules and that the aerobic reactor is an effective technique to treat industrial wastewater (Coughlin et al., 2002; Coughlin et al., 2003; Buitron et al., 2004; Ge et al., 2004; Sandhaya et al., 2005; Steffan et al., 2005; Sudarjanto et al., 2006). The aerobic reactor has the advantage of being a closed and comparatively homogeneous and stable ecosystem. Since little is known about this ecosystem, a molecular inventory is the first step to describe this dynamic bacterial community without cultivation (Godon et al., 1997). In order to better understand the functions of the bacterial community, a full description of the bacterial ecosystem is required (Bouallagui et al., 2004). Acquisition of DNA sequences is now a fundamental component of most phylogenetic, phylogeographic and molecular ecological studies. Single-strand conformation polymorphism (SSCP) offer a simple, inexpensive and sensitive method for detecting whether or not DNA fragments are identical in sequence, and so can greatly reduce the amount of sequencing necessary (Sunnucks et al., 2000). SSCP can be applied without any a priori information on the species and then can give a more objective view of the bacterial community. SSCP has been applied to study microbial communities from several habits including water, compost and anaerobic digesters (Duthoit et al., 2003; Bouallagui et al., 2004).

In this research, we used the mixture design in the experimental design (Minitab 14.0) to optimize the formulation of the predominant strains isolated from textile waste water plant. After biodegradation, the Chemical Oxygen Demand (COD) and percentage of decolorization were measured. The relationships between the different combinations and products were analyzed by Minitab to select the optimal bacterial combination and to investigate the aerobic degradability of a textile industry wastewater in Tunisia by an aerobic Stirred Bed Reactor (SBR).

\section{Materials and methods}

\subsection{Materials}

The microbial strains were microcapsules of Sphingomonas paucimobilis $\left(14 \times 10^{7} \mathrm{cfu}\right)$, Bacillus sp. $\left(4.2 \times 10^{8} \mathrm{cfu}\right)$ and Staphylococcus epidermidis $\left(7 \times 10^{9} \mathrm{cfu}\right)$, which were isolated from textile Waste Water plant in KsarHellal, Tunisia. Sphingomonas paucimobilis, Staphylococcus epidermidis and Bacillus sp. were isolated in previous works of Ayed et al.2009a,b and Ayed et al 2010a,b,c with the ability of degrading azo and triphenylmethane dyes (Congo Red, Methyl Red, Methyl Orange, Malachite Green, Phenol Red, Fushin, Methyl Green and Crystal Violet). All chemicals used were of the highest purity available and of analytical grade.

\subsection{Nutrient agar preparation}

Nutrient agar was used as the growth medium for microbial isolation. For this purpose, $28 \mathrm{~g}$ of nutrient agar was dissolved in 11 of distilled water, and was then autoclaved at $121^{\circ} \mathrm{C}$ for $20 \mathrm{~min}$. After autoclaving, the agar was left to cool at room temperature for $15 \mathrm{~min}$, and it was then poured out into Sterilin (C) disposable Petri dishes. 


\subsection{Microbial strain}

The culture was cultivated and maintained by weekly transfers on to nutrient agar slants. For production experiments, the culture was revived in nutrient broth $(\mathrm{pH} 7.0)$ and freshly prepared $3 \mathrm{~h}$ old culture $\left(\lambda_{600} \mathrm{~nm}=1\right)$ prepared in Mineral Salt Medium $(\mathrm{MSM})$ at $37^{\circ} \mathrm{C}, 150$ rpm (New Brunswick Scientific Shaker, Edison, NJ) was used as the inoculum. The used medium was composed in $1000 \mathrm{ml}$ of distilled water: glucose $(1250 \mathrm{mg} / \mathrm{l})$, yeast extract (3000 mg/l), $\mathrm{MgSO}_{4}(100 \mathrm{mg} / \mathrm{l}) ;\left(\mathrm{NH}_{4}\right)_{2} \mathrm{SO}_{4}(600 \mathrm{mg} / \mathrm{l}) ; \mathrm{NaCl}(500 \mathrm{mg} / \mathrm{l}) ; \mathrm{K}_{2} \mathrm{HPO}_{4}(1360$ $\mathrm{mg} / \mathrm{l}) ; \mathrm{CaCl}_{2}(20 \mathrm{mg} / \mathrm{l}) ; \mathrm{MnSO}_{4}(1.1 \mathrm{mg} / \mathrm{l}) ; \mathrm{ZnSO}_{4}(0.2 \mathrm{mg} / \mathrm{l}) ; \mathrm{CuSO}_{4}(0.2 \mathrm{mg} / \mathrm{l}) ; \mathrm{FeSO}_{4}(0.14$ $\mathrm{mg} / \mathrm{l})$ and it was maintained at a constant $\mathrm{pH}$ of 7 by the addition of phosphate buffer (Ayed et al., 2010a,b,c).

\subsection{Acclimatization}

The acclimatization was performed by gradually exposing Sphingomonas paucimobilis, Bacillus sp. and Staphylococcus epidermidis to the higher concentrations of effluent (Kalme et al., 2006). This bacteria were grown for $24 \mathrm{~h}$ at $30^{\circ} \mathrm{C}$ in $250 \mathrm{ml}$ Erlenmeyer flasks containing in $\mathrm{g} / \mathrm{l}$ yeast extract (3.0) and glucose (1.25) ( $\mathrm{pH}$ 7.0). During the investigation, nutrient broth concentration was decreased from $90 \%(\mathrm{w} / \mathrm{v})$ to $0 \%(\mathrm{w} / \mathrm{v})$ and finally the organism was provided with effluent as sole source of nutrient. Acclimatization experiments were carried out at optimum temperature (Kalme et al., 2006).

\subsection{Operational conditions of laboratory bioreactors}

A laboratory scale aerobic bioprocess was used in this study. The aerobic system used was SBR bioreactor. The system was operated continuously at a constant temperature of $30^{\circ} \mathrm{C}$ using an external water bath. A continuous stirred tank reactor with a $500 \mathrm{ml}$ working volume was used. Mixing was assured by the continuous rotation of the magnetic stirrer. The system was first inoculated with a microbial consortia (Sphingomonas paucimobilis, Bacillus sp. and Staphylococcus epidermidis) obtained from a textile wastewater treatment plant. These inocula were selected because of the large variety of microorganisms that could be found in the biomass degrading dyes in textile wastewater, and because mixed cultures offer considerable advantages over the use of pure culture. In fact, individual strains may attack the dye molecules at different position or may use decomposition products produced by another strains for further decomposition. In fact, it is mentioned that adaptation is important for successful decolorization, and as acclimation occurred, the decolorization time becomes constant (Buitron and Quezada Moreno, 2004). The system was fed by a peristaltic pump with the textile effluent obtained from textile wastewater plant in Ksar Hellal (Tunisia), and its pH was maintained at approximately 7 . Air was provided from the bottom of the aeration of the combined bacterial process using diffusers and an air pump. Bioreactors operating conditions were (COD: 1700 (mg O $2 / 1)$; BOD 5400 (mg O $2 / 1)$; Color : 3600 (U.C); pH: 7; MES: 810 (mg/l)).

\subsection{Analytical methods}

The effluent from each bioreactor was collected daily, centrifuged at $6000 \mathrm{rpm}$ for $10 \mathrm{~min}$ and analysed for color, COD, pH, volatile suspended solids (VSS) and colonies forming units (cfu). COD and color measurements were carried out on the clear supernatant. Color was measured by an UV-vis spectrophotometer (Spectro UV-Vis Double Beam PC Scnning spectrophotomètre UVD-2960) at a wavelength of $275 \mathrm{~nm}$ in which maximum absorbance spectra was obtained. The decolorization and COD removal were calculated according to the following formulation (Eq 1and Eq 2) (Ayed et al., 2009a,b). 
In this study, Sphingomonas paucimobilis, Bacillus sp. and Filamentous bacteria were used as mixture starters, with different proportions ranging from 0 to $100 \%$, as shown in Table 1 . Decolorization experiments were taken according to the ratio given by the experimental design, and $10 \%$ of mixed culture were inoculated into the effluent $(3.0 \mathrm{~g} / 1$ yeast extract and $1.25 \mathrm{~g} / 1$ glucose) at $37^{\circ} \mathrm{C}$ for $10 \mathrm{~h}$ in shaking conditions (150 rpm) (Ayed et al., 2010a,b,c).

$$
\% \text { Decolorization }=\frac{(\mathrm{I}-\mathrm{F})}{\mathrm{I}} \times 100
$$

Where I was the initial absorbance and $\mathrm{F}$ the absorbance at incubation time $\mathrm{t}$

$$
\operatorname{COD} \text { removal }(\%)=\frac{\text { initial } \operatorname{COD}(0 \mathrm{~h})-\text { observed } \operatorname{COD}(\mathrm{t})}{\text { initial } \operatorname{COD}(0 \mathrm{~h})} \times 100
$$

The $\mathrm{pH}$ was measured using a digital calibrated pH-meter (Inolab, D-82362 Weilheim Germany ). All assays were carried in triplicate.

\begin{tabular}{ccccccc}
\hline Assay & $\begin{array}{c}\text { Sphingomonas } \\
\text { paucimobilis }\end{array}$ & Bacillus sp. & $\begin{array}{c}\text { Staphylococcus } \\
\text { epidermidis }\end{array}$ & Total & $\begin{array}{c}\text { COD } \\
\text { Removal } \\
\mathbf{( \% )}\end{array}$ & $\begin{array}{c}\text { Decolorization } \\
\text { (\%) }\end{array}$ \\
1 & 0.66667 & 0.16667 & 0.16667 & 1.00000 & 60 & 70 \\
2 & 0.50000 & 0.50000 & 0.00000 & 1.00000 & 76 & 77 \\
3 & 0.50000 & 0.00000 & 0.50000 & 1.00000 & 77 & 88 \\
4 & 0.33333 & 0.33333 & 0.33333 & 1.00000 & 75 & 80 \\
5 & 0.00000 & 1.00000 & 0.00000 & 1.00000 & 70 & 77 \\
6 & 1.00000 & 0.00000 & 0.00000 & 1.00000 & 81 & 89 \\
7 & 0.16667 & 0.16667 & 0.66667 & 1.00000 & 53 & 63 \\
8 & 0.00000 & 0.00000 & 1.00000 & 1.00000 & 49 & 55 \\
9 & 0.00000 & 0.50000 & 0.50000 & 1.00000 & 45 & 44 \\
10 & 0.16667 & 0.66667 & 0.16667 & 1.00000 & 60 & 64 \\
\hline
\end{tabular}

Table 1. Mixture design matrix with the experimental analysis

\subsection{Pilot plant design}

As described earlier, the pilot plant comprised several treatment steps.

\section{Results and discussion}

\subsection{Model establishment}

Through linear regression fitting, the regression models of tow responses (COD \% and decolorization \%) were established. The regression model equations are as follows:

$$
\begin{aligned}
& \mathrm{Y}_{\text {decolorization } \%}=85.34 \mathrm{~S} 1+67.70 \mathrm{~S} 2+55.43 \mathrm{~S} 3+(-21.77) \mathrm{S} 1 * \mathrm{~S} 2+(67.69) \mathrm{S} 1 * \mathrm{~S} 3+(-73.59) \mathrm{S} 2 * \mathrm{~S} 3 \\
& \mathrm{R}^{2}=84.82 \% ; \mathrm{P}=0.09 \\
& \mathrm{Y}_{\mathrm{COD} \%}=77.11 \mathrm{~S} 1+70.11 \mathrm{~S} 2+49.02 \mathrm{~S} 3+(-1.55)\left(\mathrm{S} 1{ }^{* \mathrm{~S}} 2\right)+(44.27)(\mathrm{S} 1 * \mathrm{~S} 3)+(-57.73)(\mathrm{S} 2 * \mathrm{~S} 3) \\
& \mathrm{R}^{2}=75.27 \% ; \mathrm{P}=0.2
\end{aligned}
$$

Where S1: Sphingomonas paucimobilis; S2: Bacillus sp. and S3: Staphylococcus epidermidis 


\subsection{Effect of formulation on the percentage of decolorization and COD removal of}

\section{effluent}

The mixture design is now used widely in the formulation experiment of food, chemicals, fertilizer, pesticides, and other products. It can estimate the relationship between formulation and performance through regression analysis in fewer experiment times (Zhang et al., 2006).

\section{Mixture Contour Plot of COD removal (\%)}

(component amounts)

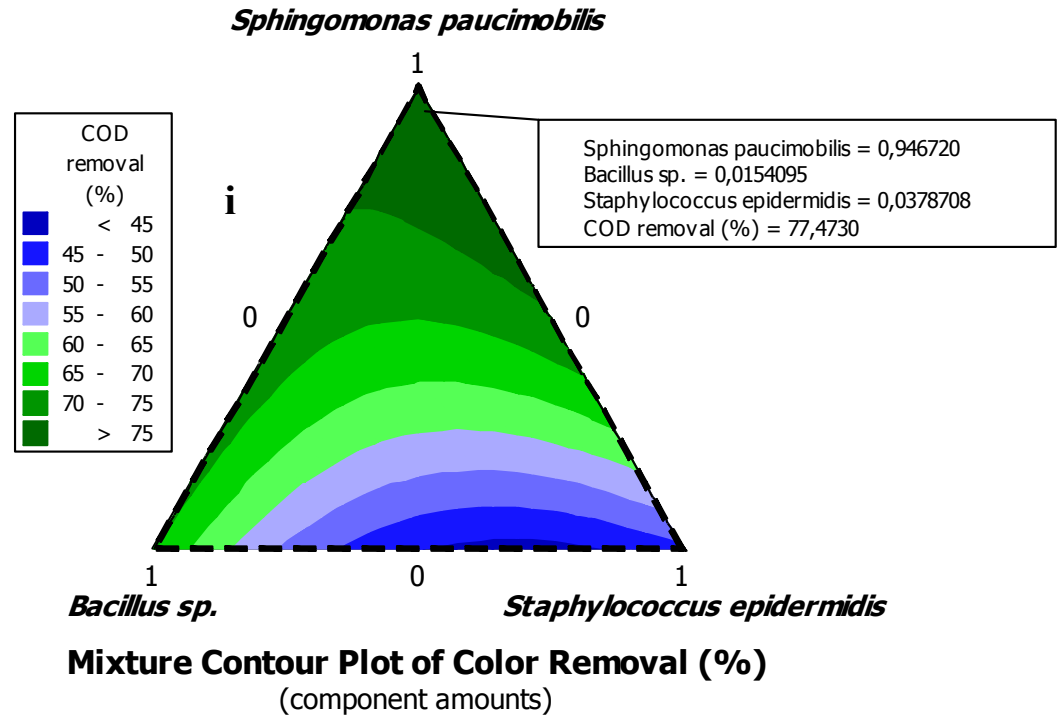

Sphingomonas paucimobilis

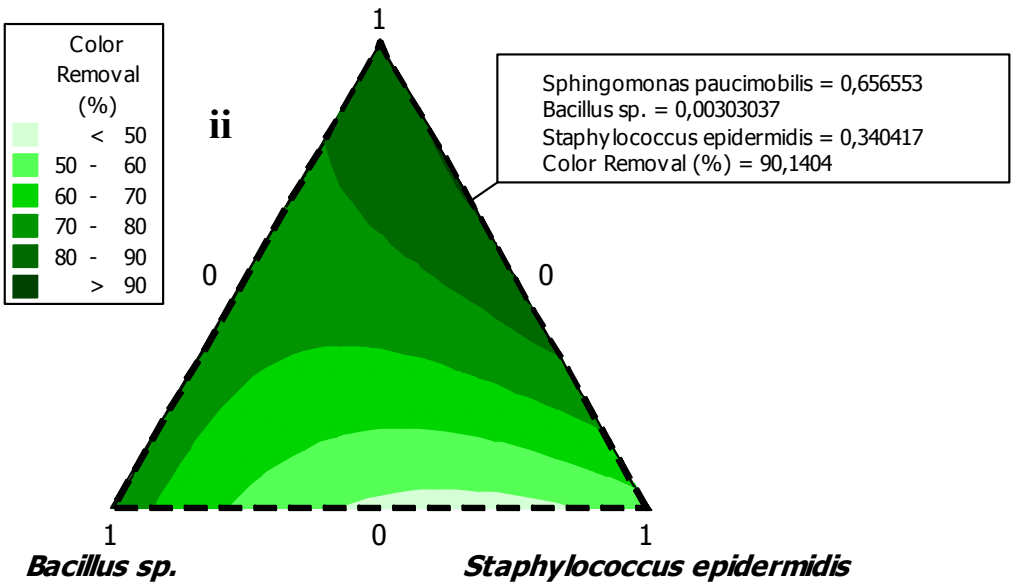

Fig. 1. Mixture contour plots between the variables (Sphingomonas paucimobilis, Bacillus sp and Staphylococcus epidermidis.) for i COD removal (\%), ii Color removal (\%). 
Zhang et al. (2006) studied the formulation of plant protein beverage using the mixture design, obtaining the optimized combination of walnut milk, peanut milk, and soy milk. In the mixture design, the effect of the change of variables on the responses can be observed on the ternary contour map. Figure 1 shows the effect of the interaction of Sphingomonas paucimobilis, Bacillus sp. and Staphylococcus epidermidis on the decolorization of effluent; Figure 1 shows the effect of the interaction of Sphingomonas paucimobilis, Bacillus sp. and Staphylococcus epidermidis on the variation of COD. The statistical significance of the ratio of mean square variation due to regression and mean square residual error was tested using analysis of variance. ANOVA is a statistical technique which subdivides the total variation in a set of data into component parts associated with specific sources of variation for the purpose of testing hypotheses on the parameters of the model.

Only results obtained for decolorization and COD removal were presented herein for clarity of purpose. According to the ANOVA (Table 2 and 3), the regression adjusted average squares were (305.8) and (231), the linear regression adjusted average squares were (1529.3) and (1115.02) allowed the calculation of the Fisher ratios ( $F$-value) for assessing the statistical significance. The model $F$-value (4.33) and (2.43) implies that most of the variation in the response can be explained by the regression equation.

$\begin{array}{ccccccc}\text { Source } & \begin{array}{c}\text { Degrees } \\ \text { of } \\ \text { freedom }\end{array} & \begin{array}{c}\text { Sum of } \\ \text { square }\end{array} & \begin{array}{c}\text { Sum of } \\ \text { adjusted } \\ \text { squares }\end{array} & \begin{array}{c}\text { adjusted } \\ \text { average } \\ \text { squares }\end{array} & F \text {-ratio } & \begin{array}{c}P \text {-value } \\ \text { (significance) }\end{array}\end{array}$

\begin{tabular}{lcccccc}
\hline Regression & 5 & 1529,3 & 1529,303 & 305,861 & 4,33 & 0,090 \\
Linear regression & 2 & 996,33 & 521,279 & 260,639 & 3,69 & 0,123 \\
Quadratic regression & 3 & 532,97 & 532,970 & 177,657 & 2,52 & 0,197 \\
Residual error & 4 & 282,30 & 282,297 & 70,574 & & \\
\hline
\end{tabular}

Total $9 \quad 1811,60$

Table 2. Analysis of variance of \% decolorization (ANOVA) for the selected linear and interactions model for effluent textile wastewater

The $P$-value for the regression obtained $\mathrm{R}^{2}=84.82 \% ; \mathrm{P}=0.09$ for decolorization was less than 0.1 and means consequently that at least one of the term in the regression equation has significant correlation with the response variable.

The associated $P$-value is used to judge whether $F$-ratio is large enough to indicate statistical significance. A $P$-value is more than 0.1 (i.e. $\alpha=0.05$ or $95 \%$ confidence) indicates 
that the model is not to be considered statistically significant. The non-significant value of lack of fit $(>0.05)$ revealed that the quadratic model is statistically significant for the response and therefore it can be used for further analysis (Zhou et al., 2007). The ANOVA test also shows a term for residual error, which measures the amount of variation in the response data left unexplained by the model (Xudong and Rong, 2008).The collected data were analyzed by using Minitab® 14 Statistical Software for the evaluation of the effect of each parameter on the optimization criteria. In order to determine the effective parameters and their confidence levels on the color removal process, an analysis of variance was performed. A statistical analysis of variance (ANOVA) was performed to see which process parameters were statistically significant. $F$-test is a tool to see which process parameters have a significant effect on the dye removal value. The $F$-value for each process parameter is simply a ratio of the mean of the squared deviations to the mean of the squared error. The color removal from the real textile wastewater was investigated in different experimental conditions.

\begin{tabular}{lcccccc}
\hline \multicolumn{1}{c}{ Source } & $\begin{array}{c}\text { Degrees } \\
\text { of } \\
\text { freedom }\end{array}$ & $\begin{array}{c}\text { Sum of } \\
\text { square }\end{array}$ & $\begin{array}{c}\text { Sum of } \\
\text { adjusted } \\
\text { squares }\end{array}$ & $\begin{array}{c}\text { adjusted } \\
\text { average } \\
\text { squares }\end{array}$ & F-ratio & $\begin{array}{c}P \text {-value } \\
\text { (significance) }\end{array}$ \\
\hline Regression & 5 & 1155,02 & 1155,023 & 231,005 & 2,43 & 0,205 \\
Linear regression & 2 & 885,44 & 470,406 & 235,203 & 2,48 & 0,199 \\
Quadratic regression & 3 & 269,58 & 269,578 & 89,859 & 0,95 & 0,498 \\
Residual error & 4 & 379,48 & 379,477 & 94,869 & & \\
\hline Total & 9 & 1534,50 & & & & \\
\hline
\end{tabular}

Table 3. Analysis of variance of COD\% (ANOVA) for the selected linear and interactions model for effluent textile wastewater

The mixture surface plots (Figure 2), which are a three-dimensional graph, was represented using COD and color removal were represented based on the simultaneous variation of Sphingomonas paucimobilis, Bacillus sp. and Staphylococcus epidermidis in the consortium composition ranging from 0 to $100 \%$ for each strain. The mixture surface plot also describing individual and cumulative effect of these three variables and their subsequent effect on the response (Liu et al., 2009; Ayed et al., 2010b,c).

The mixture contour plots between the variables such as Sphingomonas paucimobilis, Bacillus sp. and Staphylococcus epidermidis are given in Figure 2. The lines of contour plots predict the values of each response at different proportion of Sphingomonas paucimobilis, Bacillus sp. and Staphylococcus epidermidis. These values are more or less same to the experimental values. 


\section{Mixture Surface Plot of COD removal (\%)}

(component amounts)

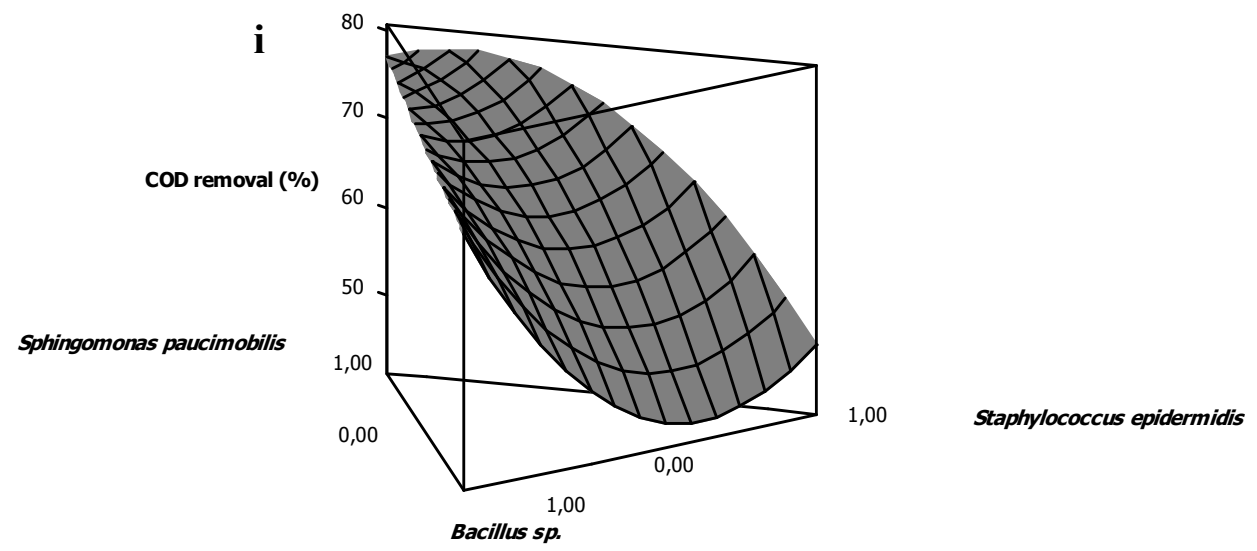

\section{Mixture Surface Plot of Color Removal (\%)}

(component amounts)

ii

Color Removal (\%)

Bacillus sp.

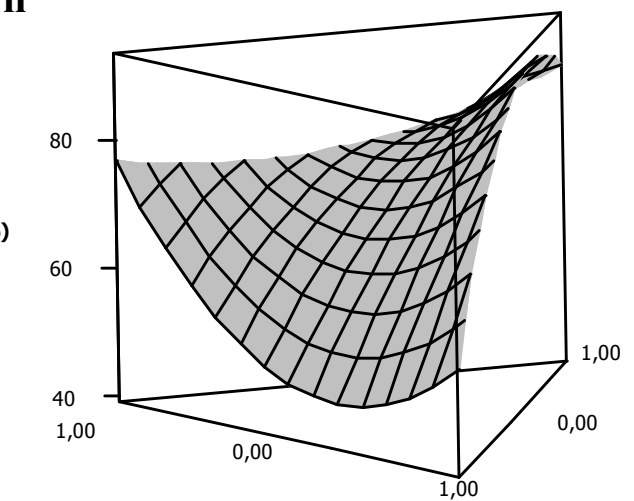

Sphingomonas paucimobilis

Staphylococcus epidermidis

Fig. 2. Mixture surface plots between the variables (Sphingomonas paucimobilis, Bacillus sp and Staphylococcus epidermidis.) for i COD removal (\%), ii Color removal (\%).

\section{Conclusions}

The developed consortium showed a better decolorization yields as compared to pure cultures, which proved a complementary interaction among various isolated bacteria. The consortium achieved significantly a higher reduction in color $(90.14 \%)$ and COD removal $(77.47 \%)$ in less time (96h). The biodegradation of the effluent textile wastewater was achieved by the developed consortium using Sphingomonas paucimobilis, Bacillus sp. and Staphylococcus epidermidis. 


\section{References}

Bouallagui, H., Torrijos, M., Godon, J.-J., Moletta, R., Ben-Cheik, R., Touhami, Y., Delegenes, J.-P., Hamdi, M., 2004. Microbial monitoring by molecular tools of a two-phase anaerobic bioreactor treating fruit and vegetable wastes. Biotechnol. Lett. 26, 857862.

Buitron, G., Quezada, M., Moreno, G., 2004. Aerobic degradation of the azo dye acid red 151 in a sequencing batch biofilter. Bioresour. Technol. 92, 143-149.

Duthoit, F., Godon, J.-J., Montel, M.-C., 2003. Bacterial community dynamics during production of registered designation of origin salers cheese as evaluated by $16 \mathrm{~S}$ rRNA gene single-strand conformation polymorphism analysis. Appl. Environ. Microbiol. 69, 3840-3848.

Khelifi, E., Gannoun, H., Touhami, Y., Bouallagui, H., Hamdi, M., 2008. Aerobic decolourization of the indigo dye-containing textile wastewater using continuous combined bioreactors. J. Hazard. Mater. 152, 683-689.

Kornaros, M., Lyberatos, G., 2006. Biological treatment of wastewaters from a dye manufacturing company using a trickling filter. J. Hazard. Mater. 136, 95-102.

Manu, B., Chaudhari, S., 2003. Decolourization of indigo and azo dyes in semi continuous reactors with long hydraulic retention time. Process Biochem. 38, 1213-1221.

Forgas, E., Cserhati, T., Oros, G., 2004. Removal of synthetic dyes wastewaters: a review. Environ. Int. 30, 953-971.

Godon, J.-J., Zumstein, E., Darbert, P., Habouzit, F., Moletta, R., 1997. Molecular bacterial diversity of an anaerobic digester as determined by small-subunit rDNA sequence analysis. Appl. Environ. Microbiol. 63, 2802-2813.

Hongman, H., Jiti, Z., Jing, W., Cuihong, D., Bin, Y., 2004. Enhancement of laccase production by $\mathrm{P}$. ostreatus and its use for the decolourization of anthraquinone dye. Process Biochem. 39, 1415-1419.

Nyanhongo, G.S., Gomes, J., Gubitz, G.M., Zvauya, R., Read, J., Steiner, W., 2002. Decolorization of textile dyes by laccases froma newly isolated strain of Trametes modesta. Water Res. 36, 1449-1456.

Khelifi, E., Gannoun, H., Touhami, Y., Bouallagui, H., Hamdi, M., 2008. Aerobic decolourization of the indigo dye-containing textile wastewater using continuous combined bioreactors. J. Hazard. Mater. 152, 683-689.

Ge, Y., Yan, L., Qinge, K., 2004. Effect of environment factors on dye decolourization by P. sordida ATCC90872 in an aerated reactor. Process Biochem. 39, 1401-1405.

Coughlin, M.F., Kinkle, B.K., Bishop, P.L., 2002. Degradation of acid orange 7 in an aerobic biofilm. Chemosphere 46, 11-19.

Coughlin, M.F., Kinkle, B.K., Bishop, P.L., 2003. High performance degradation of azo dye acid orange 7 and sulfanilic acid in a laboratory scale reactor after seeding with cultured bacterial strains. Water Res. 37, 2757-2763.

Sandhaya, S., Padmavathy, S., Swaminathan, K., Subrahmanyam, Y.V., Kaul, S.N., 2005. Microaerophilic-aerobic sequential batch reactor for treatment of azo dyes containing simulated wastewater. Process Biochem. 40, 885-890.

Steffan, S., Badri, L., Marzona, M., 2005. Azo dye biodegradation by bacterial cultures immobilized in alginate beads. Environ. Int. 31, 201-205. 
Sudarjanto, G., Lehmann, B.K., Keller, J., 2006. Optimization of integrated chemicalbiological degradation of a reactive azo dye using response surface methodology. J. Hazard. Mater. B138, 160-168.

Sunnucks, P., Wilson, A.C.C., Beheregaray, L.B., Zenger, K., French, J., Taylor, A.C., 2000. SSCP is not so difficult: the application and utility of single stranded conformation polymorphism in evolutionary biology and molecular ecology. Mol. Ecol. 9, 1699_ 1710.

Suwardiyono,T.S , Wenten,I.G.. ( 2005 ) Treatment of Textile Wastewater by a Coupling of Activated Sludge Process with Membrane Separation Journal of Water and Environment Technology, 3,125-136

Thomas, B., Aurora, T., Wolfgang, S., 2006. Electrochemical decolourization of dispersed indigo on boron-doped diamond anodes. Diamond Relat. Mater. 15, 1513-1519. 


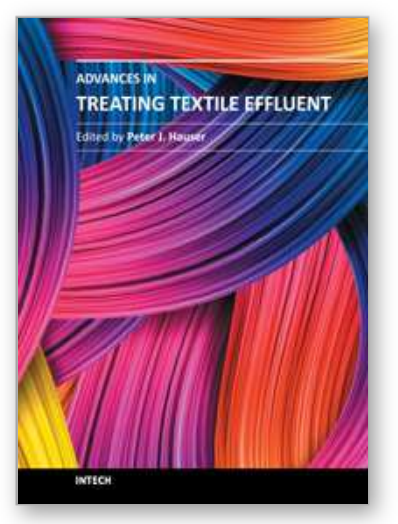

\author{
Advances in Treating Textile Effluent \\ Edited by Prof. Peter Hauser
}

ISBN 978-953-307-704-8

Hard cover, 154 pages

Publisher InTech

Published online 26, October, 2011

Published in print edition October, 2011

The treatment of textile wet processing effluent to meet stringent governmental regulations is a complex and continually evolving process. Treatment methods that were perfectly acceptable in the past may not be suitable today or in the future. This book provides new ideas and processes to assist the textile industry in meeting the challenging requirements of treating textile effluent.

\title{
How to reference
}

In order to correctly reference this scholarly work, feel free to copy and paste the following:

Lamia Ayed and Amina Bakhrouf (2011). Pilot Plant Experiences Using Activated Sludge Treatment Steps for the Biodegradation of Textile Wastewater, Advances in Treating Textile Effluent, Prof. Peter Hauser (Ed.), ISBN: 978-953-307-704-8, InTech, Available from: http://www.intechopen.com/books/advances-in-treatingtextile-effluent/pilot-plant-experiences-using-activated-sludge-treatment-steps-for-the-biodegradation-oftextile-was

\section{INTECH}

open science | open minds

\section{InTech Europe}

University Campus STeP Ri

Slavka Krautzeka 83/A

51000 Rijeka, Croatia

Phone: +385 (51) 770447

Fax: +385 (51) 686166

www.intechopen.com

\section{InTech China}

Unit 405, Office Block, Hotel Equatorial Shanghai

No.65, Yan An Road (West), Shanghai, 200040, China 中国上海市延安西路65号上海国际贵都大饭店办公楼 405 单元

Phone: +86-21-62489820

Fax: $+86-21-62489821$ 
(C) 2011 The Author(s). Licensee IntechOpen. This is an open access article distributed under the terms of the Creative Commons Attribution 3.0 License, which permits unrestricted use, distribution, and reproduction in any medium, provided the original work is properly cited. 